\title{
THE PORTFOLIO OF EVIDENCE IN THE COMPETENCY-BASED EDUCATIONAL MODEL OF THE UNIVERSITY OF GUANAJUATO
}

\author{
María Guadalupe Arredondo-Hidalgo ${ }^{1}, \boldsymbol{\&}$ Diana del Consuelo Caldera González ${ }^{2}$ \\ ${ }^{1}$ Department of Business Management and Administration, University of Guanajuato/Fulltime professor \\ (Mexico) \\ ${ }^{2}$ Department of Organizational Studies, University of Guanajuato/ Fulltime professor (Mexico)
}

\begin{abstract}
In a teaching-learning process, it is essential that the evaluation is summative and formative, from an analytical and holistic basis so that the process is comprehensive and integrates the work that the student has developed throughout the course, for example, a portfolio of evidence. Van der Schaaf and Stokking (2008) state that a portfolio of evidence integrates elements that must be related to each other, in order to be considered valid and reliable to evaluate the teaching-learning process, the elements are: a) the teacher model, b) the task model, c) the scoring model and d) the interpretation model. The objective of this research is to analyze the use of the portfolio of evidence as an evaluation tool within the teaching-learning process, for the Competency-Based Educational Model of the University of Guanajuato. This is a quantitative research with descriptive scope. A 22-item questionnaire was used considering the instrument developed by Romero and Crisol (2011) called "Opinion, satisfaction, usefulness and feelings of students about the use of the portfolio in learning and self-evaluation". The instrument was applied to a sample of 183 students of the Bachelor's Degree in International Commerce of the Economic-Administrative Sciences Division of the University of Guanajuato, distributed in four different Learning Units. The results indicate that students consider important the use of the portfolio of evidence as part of their teaching-learning process. In the part of satisfaction, usefulness and feelings, the students consider that the use of the portfolio is very important as a pertinent and adequate tool, and it is considered useful for learning, since besides serving as reinforcement, it implies a free and creative exercise. As conclusions of the study, the importance of the portfolio of evidence as a method of evaluation in accordance with the Educational Model by Competencies of the University of Guanajuato, which has also been well received at least by the sample of this study, is manifested. As future lines of research, it is expected to expand the sample to other careers and learning units to verify the replicability of the results of the study.
\end{abstract}

Keywords: Competency-based education model, portfolio of evidence, higher education institutions.

\section{Introduction}

It is relevant to associate the competency-based educational model in Higher Education Institutions, so the association of the taught contents of the subjects with the objectives and results of the teaching-learning process becomes valuable. In this regard, Van der Schaaf and Stokking (2008) establish that a portfolio of evidence considers elements that must be related to each other, in order to be considered valid and reliable. These are: a. The teacher model, b. The task model, c. The scoring model and $\mathrm{d}$. The interpretation model. It is essential that the evaluation is summative and formative, from the analytical and holistic basis, considering all the scenarios so that the learning process is comprehensive and considers the work that the student has developed for the content of their evidence portfolio.

Barragán (2005, p. 122) indicates that the term portfolio is understood as: "a technique of compilation, collection and repertoire of evidence and professional competencies that enable a person for satisfactory professional development". As understood in the context that, as faculty members, we are developing university talents that will be incorporated in the short term to a labor market, that increasingly demands that graduates know how to do a job, based on the knowledge they have acquired in the classroom. Pérez (2013) addresses the scenario of the application of the evidence portfolio especially for the competency-based model, as fundamental to understand how it can be applied as a tool for application in university students and quotes De Ketele (2008) who identifies five stages in the evolution of knowledge and knowledge, these are presented in the following Figure 1. 
Figure 1. Stages of learning and knowledge.

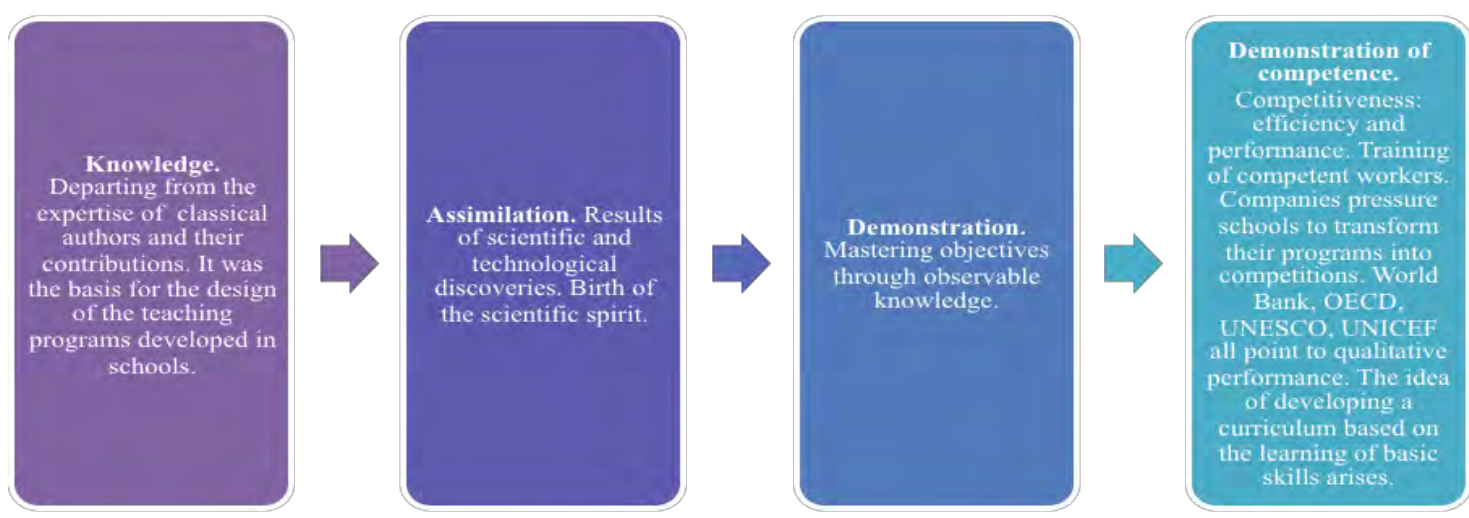

Source: own elaboration based on Pérez-Rendón (2014) and De Ketele (2008).

Subsequent to these stages, De Ketele (2008) proposes a new movement that would be characterized by a more holistic approach, whose mission should be oriented to the development of knowledge "to live in a world in permanent and rapid change". Díaz Barriga (2011) explains that the concept of competences applied in education is certainly recent and involves elements of the social context of the late 20 th and early 21 st centuries. Society is the one who dictates the interests to promote formal education in order to achieve tangible results to develop certain skills in the student, which allows them to join the world to work effectively. This is also the consequence of globalization, both from the system and its people, since the skills in education must be linked to the policies that countries like Mexico apply in their education sector. Given the above, Aguerrondo (2009) establishes that the "challenge of educational reforms is not what the school is for the future, but how the new society solves the need for equitable distribution of knowledge, which characteristics this knowledge must have in order to fit what is 'socially valid' and how the social environment is organized 'to make lifelong learning possible"'(p. 4). UNESCO indicates that the competency-based model must be focused on learning since the student is the center of attention, it must promote comprehensive and high-quality training, as well as provide a solid training from the student having autonomous learning. Taking this into account as a whole, this should promote "flexible, innovative processes that allow the movement of students between educational levels and multiple spaces of relationship with the environment". In this way, the analysis of the interest of measuring the perception of the students around the portfolio of evidence, becomes pertinent in order to identify changes in the way in which the subject is developed in International Trade students. Additionally, it is important to mention that in the document entitled: Guidelines for graduation or obtaining a degree in the educational programs of the Division of Economic-Administrative Sciences of the University of Guanajuato, the presentation of the evidence portfolio is established as a degree option, which is defined as: "a set of evidence such as documents, manuals, diagrams, photographs, models, etc., either in physical or digital form that a student has developed throughout different Learning Units (LU) and are the evidence of the meaningful acquired learning”. Based on the above, the relevance of the research is aligned, both to the educational model and to the degree indicators.

As determined by Romero and Crisol (2011), the portfolio of evidence has the following characteristics:

- It belongs to the student and it is their responsibility. They decide the meaning of it, the way they apply their reflection, so that it becomes a unique experience of self-evaluation of a personal nature.

- The students are the ones who must compile the evidence of their learning, applying a logic that leads them to organize the information in a way that makes sense to them. "The selection will be accompanied by a reflection on the value of each of the chosen documents."

- The student chooses how to design their own portfolio.

- The portfolio is made up of a field diary where the student captures their reflections on what they have learned.

- The portfolio contains all the documents to record the activities that have been carried out under the tutelage of the teacher.

March (2004) quotes Donnay (1996) and indicates that initially, one of the lines of the academic profession is the reflection on practice; it is settled that this is an essential element for teachers to adapt into the challenges of a changing society that demands the realization of daily professional tasks. Secondly, it is about the university professor applying teamwork and collaboration among students: "the culture of collaboration is one of the fundamental strategies for innovation, as well as for professional development, since it is an element that originates satisfaction in the subjects, which will decisively 
influence the quality of the institution" (p. 129). Finally, it is indicated that there must be a link between the pedagogical approaches, the preparation of didactic materials and the procedures to carry out evaluations, all of this starting, also, from the requirement of the ethical dimension in the teaching profession. The specific key questions of the following investigation are: How do students perceive the use of the portfolio? Is it useful for the teaching-learning process? What changes or adjustments should be considered in order to apply the correct assessment to make this process holistic? Martínez-Sánchez (2002) states that the student must possess the evidence of the learning that has been acquired, and the portfolio of evidence must be a valuable tool to achieve teaching-learning.

The portfolio of evidence has been instituted as a form of evaluation for the students in the last semesters of the bachelor's degree in International Trade, for the subjects of International Business, Impact of Logistics on Business Management and Methodology and Preparation of Reports, respectively. It is proposed that this document must be elaborated as follows.

Figure 2. Cover proposal for the Evidence Portfolio.

\begin{tabular}{|c|c|c|}
\hline \multicolumn{3}{|c|}{ EVIDENCE PORTFOLIO OF THE ASSIGNMENT: } \\
\hline STUDENT: & & \\
\hline GROUP-SEMESTER: & & \\
\hline ASSIGNMENT: & & \\
\hline TOPIC-DATE & EVIDENCES: & VALUE: \\
\hline
\end{tabular}

PROFESSOR:

teacher's signature-follow-up

The specific activities are: lecture and video reports, mind maps, reports from official internet pages (World Customs Organization (WCO), World Trade Organization (WTO), Logistics Performance Index as well as repositories of information from sources like EBSCO, Emerald, etc).

\section{Methodology}

In order to know how students perceive their learning experience from the evidence portfolio, a questionnaire was applied. The questionnaire was entitled: "Opinion, satisfaction, usefulness and feelings of students about the use of the portfolio in learning and self-assessment", by the authors Romero and Crisol (2014). It was applied to 183 students of the Bachelor of International Trade. The questionnaire consisted of 22 items in total, the first 17 response items being Likert scale from 1 to 4 ( 1 = Not important at all, 2 = Somewhat important, $3=$ Important and $4=$ Very important), and the last 5 items of multiple selection. Of the 22 items that make up the instrument, the first 14 are intended to assess the achievement of the objectives pursued with the completion of the portfolio, the following 3 items assess the satisfaction, usefulness and tutoring of the tool, and the last 5 items are aimed at acknowledgement of the sensations (emotions) experienced in the students after completing the portfolio. The Cronbach's alpha of the entire instrument was 0.890 for the total items of the questionnaire, which means that it is highly reliable for the objective of the present investigation. The dimensions involved were:

1. The students' opinion. Satisfaction of the portfolio as a tool for learning.

2. Portfolio profit.

3. The students' feelings towards the usefulness of the portfolio.

Sample: 183 students from the bachelor's degree in International Trade were surveyed for the subjects of: Impact of International Logistics on Business Management, Methodology and Reporting, International Trade, World Geography Workshop and International Business.

\section{Results}

The results obtained with the application of the questionnaire are shown below. According to the evaluated dimensions as well as the achievements of the pursued objectives regarding the completion of the portfolio, the following behavior was observed: the students showed a very brief knowledge about the system by competencies and the ideology of the University of Guanajuato, however, most believe that the portfolio helps them to set clear objectives in their learning process. The reliable statistic data: Cronbach's Alpha: 857 of 14 elements. Cronbach's Alpha based in the typified elements: 0.855 . 
Table 1. Dimension: Assess the achievement of the objectives pursued with the completion of the portfolio.

\begin{tabular}{|c|c|c|c|c|c|}
\hline & $\mathrm{N}$ & Minimum & Maximum & Median & Typ. Desv. \\
\hline A01 & 183 & 1 & 4 & 2.89 & .758 \\
\hline A02 & 183 & 1 & 4 & 3.03 & .762 \\
\hline A03 & 183 & 2 & 4 & 3.77 & .485 \\
\hline A04 & 183 & 1 & 4 & 3.52 & .645 \\
\hline A05 & 183 & 2 & 4 & 3.60 & .583 \\
\hline A06 & 183 & 1 & 4 & 3.36 & .742 \\
\hline A07 & 183 & 2 & 4 & 3.30 & .689 \\
\hline A08 & 183 & 1 & 4 & 3.33 & .758 \\
\hline A09 & 183 & 1 & 4 & 3.26 & .701 \\
\hline A10 & 183 & 1 & 4 & 3.34 & .753 \\
\hline A11 & 183 & 1 & 4 & 3.27 & .825 \\
\hline A12 & 183 & 1 & 4 & 3.00 & .791 \\
\hline A13 & 183 & 1 & 4 & 2.91 & .775 \\
\hline A14 & 182 & 1 & 4 & 3.25 & .759 \\
\hline & & & & 3.27 & \\
\hline
\end{tabular}

However, in the rest of aspects, to achieve the pursued objectives with the evidence portfolio, the resulted average of 3.27 indicates that students consider the use of the evidence portfolio as part of their teaching-learning process important.

Table 2. Dimension: satisfaction, usefulness and tutoring of the tool.

\begin{tabular}{|c|c|}
\hline \multicolumn{2}{|c|}{ Reliable statistic data } \\
\hline Cronbach's Alpha & N of elements \\
\hline .629 & 3 \\
\hline
\end{tabular}

\begin{tabular}{|r|c|r|r|r|r|}
\hline \multicolumn{7}{|c|}{ Descriptive statistics } \\
\hline & $\mathrm{N}$ & Minimum & Maximum & Median & Typ. Desv \\
\hline A15 & 183 & 1 & 4 & 3.69 & .580 \\
\hline A16 & 183 & 1 & 4 & 3.60 & .612 \\
\hline A17 & 183 & 1 & 4 & 3.40 & .742 \\
\hline & & & & 3.56 & \\
\hline
\end{tabular}

In the second dimension, satisfaction, usefulness and tutoring of the portfolio, the students consider that the use of the portfolio is very important; an average of 3.56 was obtained, this indicates that this tool is considered to be of good use for learning.

Table 3. Dimension: acknowledgement of the sensations (emotions) experienced in the students after completing the portfolio.

\begin{tabular}{|c|r|}
\hline \multicolumn{2}{|c|}{ Reliable statistic data } \\
\hline Cronbach's Alpha & N of elements \\
\hline .665 & 5 \\
\hline
\end{tabular}

\begin{tabular}{|r|c|r|r|r|r|}
\hline \multicolumn{5}{|c|}{ Descriptive statistics } \\
\hline & $\mathrm{N}$ & Minimum & Maximum & Median & Typ. Desv. \\
\hline A18 & 183 & 1 & 4 & 3.63 & .578 \\
\hline A19 & 183 & 1 & 4 & 3.60 & .646 \\
\hline A20 & 183 & 1 & 4 & 3.51 & .702 \\
\hline A21 & 183 & 1 & 4 & 3.64 & .611 \\
\hline A22 & 183 & 1 & 4 & 3.42 & .674 \\
\hline & & & & 3.56 & \\
\hline
\end{tabular}

For the third dimension, which measures the sensations (emotions) experienced in the students after completing the portfolio, an average of 3.56 is observed. This indicates that they are satisfied with the tool and gives them a good feeling of satisfaction. 


\section{Conclusions}

The conclusions indicate that the portfolio is a fundamental tool for students in order to achieve learning in a competency-based educational model context. When students reflect on their progress, the implementation of the perceived knowledge becomes assimilated since the students build from within the basic knowledge to become better people as well as better professionals. Aguerrondo (2008) insists that meaningful learning must be provided from a skill development education, where it can be applied in multiple areas: capacity expressed through knowledge, skills and attitudes. Likewise, he identifies four characteristics in common: competence takes the context into account; it is the result of an integration process, it is associated with performance or performance criteria, and it implies responsibility. The proper interpretation of the educational model and the academic model consequently leads us to identify the elements for the evaluation of student learning, along with the study plans. Additionally, the educational model must be updated with the graduation profile, it must be linked as well to the relevance and feasibility based on the work of the academic committees with the business sector. The academic model can be understood in how teaching is applied. The aims of the educational model are: the relevance, efficiency, coherence, transparency, competences, integrity and transversality of the University of Guanajuato. At the same time, we must apply innovation in education in order to inspire transcendence in the student's attitudes as well as to know how the material in the educational infrastructure helps us apply innovation. The perspective should be one to motivate us to learn more from these issues that will only help us to become comprehensive and complete teachers that are able to apply the benefits of progress within our practice. Finally, it is a challenge to insist that students become acquainted with the ideology and philosophy of the University of Guanajuato, as well as the competency-based model, since they do not share or do not know the concepts. It would be convenient to inquire why, however, as teachers and tutors it is important to continue guiding their path so that they know that these tools are designed for their benefit.

\section{References}

Aguerrondo, I. (2008). Documento Técnico de la UNESCO. Conocimiento complejo y competencias educativas.

Barragán, R. (2005). El Portafolio, metodología de evaluación y aprendizaje de cara al nuevo Espacio Europeo de Educación Superior. Una experiencia práctica en la Universidad de Sevilla. Revista Latinoamericana de Tecnología Educativa, 4(1), 121-139. Recuperado de: http://www.unex.es/didactica/RELATEC/ sumario_4_1.htm.

De Ketele, J. M. (2008). Enfoque socio-hist rico de las competencias en la ense anza, Profesorado. Revista de curr culo y formaci $n$ del profesorado, 12, (3). Recuperado de: http://www.ugr.es/local/recfpro/rev123ART1.pdf

Díaz-Barriga, Á. (2011). Competencias en educación. Corrientes de pensamiento e implicaciones para el currículo y el trabajo en el aula. Revista Iberoamericana de Educación Superior, II(5) 3-24. Recuperado de http://www.redalyc.org/articulo.oa?id=299123992001

Fernández-March, A. (2004). El portafolio docente como estrategia formativa y de desarrollo profesional. Revista Educar 33, 127-142. Recuperado de http://www.raco.cat/index.php/educar/article/viewFile/20792/20632

Mart nez-S nchez, N. (2002). El portafolio como mecanismo de validaci $\mathrm{n}$ de aprendizaje. Perfiles Educativos, vol. XXIV, n m. 95, 2002, pp. 54-66 Instituto de Investigaciones sobre la Universidad y la Educaci n Distrito Federal, $M$ xico.

Pérez, Rendón, M. (2014). Perspectiva Educacional. Formaci n de Profesores Enero 2014, Vol. 53(1), Pp. 19-35 doi: 10.4151/07189729-Vol.53-Iss.1-Art.213

Romero-López, A. y Crisol, E. (2011). El portafolio, herramienta de autoevaluación del aprendizaje de los estudiantes. Una experiencia práctica en la Universidad de Granada. Revista Docencia e Investigación. $\quad$ No. $\quad 21 . \quad$ Recuperada de http://www.uclm.es/varios/revistas/docenciaeinvestigacion/pdf/numero11/02.pdf

Universidad de Guanajuato. División de Ciencias Económico Administrativas. Campus Guanajuato. (2018). Lineamientos para la Titulación u Obtención de grado en los programas educativos de la División de Ciencias Económico Administrativas.

Van der Schaaf, M. F. y Stokking, K.M. (2008). Developing and validating a design for teacher portfolio assessment. Assessment \& Evaluation in Higher Education, 33 (3), 245-262. 